\title{
Comic book for improving the elementary school students' mathematical problem solving skills and self-confidence
}

\author{
Suryatin Suryatin $^{1}$, Sugiman Sugiman ${ }^{2}$ \\ ${ }^{1}$ Sekolah Tinggu Keguruan dan Ilmu Pendidikan (STKIP) PGRI Pacitan \\ Jalan Cut Nya' Dien No. 4A Pacitan, 63515, Indonesia \\ ${ }^{2}$ Universitas Negeri Yogyakarta. Jalan Colombo No. 1, Karangmalang, Yogyakarta, 55281, Indonesia \\ *Corresponding Author. Email: suryanisa733@gmail.com \\ Received: 30 August 2016; Revised: 29 January 2019; Accepted: 21 May 2019
}

\begin{abstract}
The study aims at generating a product in the form of comic book and also displaying the feasibility and the effectiveness of the comic book in improving the mathematical problem-solving skills and the self-confidence of the Grade IV students in the Muhammadiyah Elementary School Condongcatur Yogyakarta. The study is a Research and Development initiative (R\&) with reference to 10 stages that have been developed by Borg \& Gall. During the conduct of the study, the subjects were the Grade IV students of Muhammadiyah Elementary School Condongcatur Yogyakarta. The results of the study show that: (1) a comic book-based learning media that meet the criteria of feasibility based on the validation results by the material expert, the media expert, the teacher response and the students response have been generated with "Good" category; and (2) the comic book-based learning media that have been generated are effective for improving the students' mathematical problem-solving skills and also the students' self-confidence.

Keyword: research and development, comic, mathematical problem-solving skills and self-confidence How to Cite: Suryatin, S., \& Sugiman, S. (2019). Comic book for improving the elementary school students' mathematical problem solving skills and self-confidence. Jurnal Prima Edukasia, 7(1), 58-72. doi:https://doi.org/10.21831/jpe.v7i1.10747
\end{abstract}

do https://doi.org/10.21831/jpe.v7i1.11291

\section{Introduction}

In the elementary school, learning is the preliminary process for building numerous character values, knowledge and skills. The statement is in accordance to the Ministry of National Education Regulation which has mandated that elementary school aims at setting forth the basis of intelligence, knowledge, personality, noble characteristics, skills for pursuing independent life and pursunce on higher education.

The Ministry of Education and Art (Kementerian Pendidikan dan Kebudayaan, 2014 , p.vii) states that the graduates of elementary school are expected to perform and to implement the productive and creative thinking skills in both the abstract domain and the concrete domain. The achievement of the competencies that have been formulated is designed through discovery-based learning process with the learning activities that take the form of assignments and problem-solving situations. In this regard, the learning approach that has been adopted is the thematic-integrative approach that integrates numerous competencies frim multiple subjects into multiple themes.

The implementation of thematic-integrative learning process in the elementary school, however, has encountered several challenges. These challenges are mainly perceived by the teachers who have been directly involved within the learning process in the field (school). The replacement of Educational Unit Level Curriculum (KTSP, Kurikulum Tingkat Satuan Pendidikan) by 2013 Curriculum (Kurikulum 2013) ensures the presence of the teachers' adjustment toward the thematic integrative model. This adjustment might be a peculiar challenge for the teachers, especially the teachers who have been used to teach one subject to another separately. In addition, the assessment process in 2013 Curriculum is also different than the assessment process in Educational Unit Level Curriculum.

Such challenge has also been perceived by the Grade IV teachers of Muhammadiyah 
Jurnal Prima Edukasia, 7 (1), 2019 - 59

Suryatin Suryatin, Sugiman Sugiman

Elementary School Condongcatur Yogyakarta. The Grade IV teachers state that in the implementation of the thematic integrative learning process they have lear a lot of aspects and gradually eliminate the old teaching habits.

Not only the teachers, the Grade IV students of Muhammadiyah Elementary School Condongcatur Yogyakarta also experience similar difficulties. The students have been unable to master all competencies that have been presented in the thematic integrative learning process well. One of their difficulties is found in Mathematics namely the mathematical problem-solving skills.

The students still perceive difficulties and have low self-confidence in solving the mathematical problems. According to the information that has been retrieved from the teachers, one of the indicators for the students' low selfconfidence in Mathematics is that the students will take time and after a while they are only able to complete two test items. In other words, it might be implied that the students are still weak and surrender quickly when they have to solve the difficult Mathematics test item.

Therefore, it might be concluded that both the students and the teachers share similar problems. In 2013 Curriculum, that implements the scientific approach, the teachers admit that they need learning media that contain the thematic integrative learning materials in order to encounter the students' low problem-solving skills and self-confidence in Mathematics. In addition, the teachers also admit that the learning media that have been available in the elementary school has still been limited and they do not have sufficient time to develop the new learning media.

Not only that, the teahers have developed the new learning media for several times but unfortunately the have been unable to put the new learning media into mass production. Consequently, a research and development initiative should be performed in order to assist the teachers of Muhammadiyah Elementary School Condongcatur Yogyakarta in encountering this problem.

With regards to learning media, there are various types of learning media and one of them is pictorial segmentation. The pictorial segmentation has been frequently employed in the learning process because the students communicate easier with the pictorial segmentation rather than the compositions. The reason is that in their childhood the students are introduced with pictures first raher than the compositions (Tabrani, 2014, p.20).

One of the pictorial segmentation media is comic. The content of the comic that used to be known for its comedy now has widened into a science fiction-based content (Gumelar, 2011, p.2). Therefore, the use of comic has widened into learning media.

The comic Quark is the example of a comic that contains the learning materials of Science and might be studied by the students independently. The students who have read the comic have at least performed an activity that bring about double benefits for them. The first benefit is that the students are satisfied because they have done something that they like most namely reading a comic, while the second benefit is that the students might build their selfknowledge about Science.

Learning media as a result of technological advancement might deliver significant benefit on the teaching and learning process. The use of the media is intended to develop the students' learning capacity. According to Russell \& Schneiderheinze (2005, p.39), when technologies are inserted into the educational environment they are meant to develop learning abilities in the students.

The learning media that facilitate the students to learn actively might also bridge the interaction between the students and what they are learning (Tyagi, 2014, p.14). Sadiman, Rahardjo, Haryono, \& Rahardjito (2012, pp.1718) mentions specific functions of learning media namely minimizing verbality (only in the form of words and compositions), encountering the time and space limitation, encountering the students' passive attitude by inciting their learning enthusiasm, pursuing direct interaction between the students and their environment and reality and also enabling the students to learn independent in accordance to their interest and capacity.

The various functions of learning media encourage the academicians to develop, research and benefit the learning media in order to manifest the effective teaching and learning process among the students. In accordance to the statement, the use of comic as the learning media has been widespread throughout the globe.

Several experts have conducted their study on the use of comic and its impact in the teaching and learning process. For example, the results of a study by Cheesman (2006, pp.48-51) show that the use of comic in the learning process of Natural History is able to draw the students' 
Jurnal Prima Edukasia, 7 (1), 2019 - 60

Suryatin Suryatin, Sugiman Sugiman

interest, to provide the stimulus of critical thinking skills and to help the students in explaining the given concept. Then, Cheesman further states that some of the students attend the learning process enjoyably since the learning process is performed by means of comic book. However, not all students show positive response toward the use of comic in the teaching and learning process.

Similar study has been conducted by Indaryati \& Jailani (2015, pp.84-96) with regards to the development of comic as learning media in Mathematics for improving the students' learning motivation and achievement. The comic that has been developed within the study is related to the narrative test items about distance, time and velocity. The results of their study show that the learning process using the comic that has been developed as the learning media might improve the students' learning motivation and achievement. In addition, Saputro \& Soeharto (2015, pp.61-72) have also studied the development of character education-based comic as the media for the thematic integrative learning process. The results of their study show that the comic that has been developed is effective for improving the students' character values of discipline and responsibility. The study by Cheesman and also by Indaryati \& Jailani show that the use of comic as learning media has been able to not only improve the students' interest but also the students' cognitive thinking skills namely the critical thinking skills and the learning achievement. On the other hand, the study by Saputro \& Soeharto has shown that the use of comic might improve the students' characters. From these studies, it is clear that comic has been very popular media among the children (Tatalovic, 2009, p.1) and the statement also applies to the Grade IV students of Muhammadiyah Elementary School Condongcatur Yogyakarta. In relation to its popularity, it is apparent that comic might be benefitted for improving the cognitive skills and the characters of the students. In other words, comic might be benefitted for overcoming the problems of learning media needs in the implementation of thematic integrative learning process while improving the students' problem-solving skills and self-confidence.

Problem solving skills in Mathematics are significant competence. The mathematical usage and power will be highly limited if one does not possess problem-solving skills. For example, the students who are able to perform the multiplication accurately but unable to identify the situations that require the application of multiplication will sense the less benefit of mastering the multiplication skills. According to $\operatorname{NCTM}(2000$, p.182), without the ability to solve problems the usefulness and power of mathematical ideas, knowledge and skills are severely limited. Furthermore, problem-solving skills serve as a medium for learning about the other mathematical ideas and capacities. Problem solving is also important because it can serve as a vehicle for learning new mathematical ideas and skills (Schroeder \& Lester in NCTM, 2000, p.182). Similarly, Pimta, Tayruakham \& Nuangchalem (2009, p.381) state that problemsolving skills have impacts on the development of critical thinking method development. The skill is not only for learning the subject but it emphasizes on developing thinking skill method as well.

The term problem in problem-solving skills itself implies that problem is some kind of difficulty which solution has not been immediately found (Posamentier \& Krulik, 2009, p.2). Problem is subjective depending on the people who encounter it. As a result, in terms of Mathematics the problem for elementary school students might not be difficult for the junior high school students. Thus, if a solution to the difficulty has been found immediately then the difficulty might not be considered as a problem anymore. Departing from the definition, it might be concluded that the mathematical problems of elementary school students are different from those of junior high school students. Specifically, the mathematical problems for the elementary school students are something interesting, challenging and involving for considering about the significance of Mathematics (NCTM, 2000, p.182). Unfortunately, in the practice within the learning process on the elementary schools the differences between "exercise" and "problem" has not been described appropriately because the description depends on the students' mind (Musser, Peterson, \& Burger, 2011, p.4). However, working on exercises will be very helpful for the students to learn about the concepts, the characteristics and the procedures that later might be implemented into the efforts of solving the mathematical problems.

Reys in Runtukahu \& Kandou (2014, p.191) states that problem-solving skills especially in the educational process of Mathematics is an appropriate approach for solving the mathematical problems. On the contrary, for the elementary school students these problem- 
Jurnal Prima Edukasia, 7 (1), 2019 - 61

Suryatin Suryatin, Sugiman Sugiman

solving skills should be a process that absorbs the learning process of Mathematics and should provide a context in which the concepts and the skills for the mathematical learning process are contained. Haylock (2007, pp.145-146) state that problem solving is when the individual makes use of their thinking skills from the mathematical knowledge. The implication of the statement is that problem-solving efforts occur when an individual makes use of the mathematical knowledge that he or she has internalized in order to solve the problems that they encounter. The implementation of the knowledge that has been internalized makes the knowledge meaningful.

Problem solving skills for the elementary school students essentially involve three important and fundamental skills namely the skill of interpreting test item, the skill of selecting appropriate strategy and the skill of operating numbers (Runtukahu \& Kandou, 2014, pp.194201). The three skills are highly significant for supporting the problem-solving process. Therefore, the students should be habituated to hones these three skills. In relation to the explanation, it might be concluded that the problem-solving skills for the elementary school students refer to the students' skills in solving the mathematical problems by using their mathematical knowledge through the process of interpreting test items, selecting and using appropriate strategy and operating numbers. By doing so, the students will be able to arrive at the appropriate solution for the problems that they have to solve.

In general, the problem-solving procedures consist of four stages. These four stages, developed by Polya, are known as the heuristic model. The stages in the heuristic model consist of understanding the problem, planning the strategy, implementing the strategy and reviewing or reinspecting the strategy. Based on the stages, it might be defined that problem-solving skills are practical skills that might be internalized by means of imitation and exercise. According to Polya (1973, p.5), solving problem is a practical skill and individuals acquire any practice skill through imitation and practice. Furthermore, Ploya states that individuals who solve problems need to observe and imitate what the other people perform when they are solving their problems. Departing from this explanation, a teacher might exercise the students' problem-solving skills by providing many opportunities for the students to perform imitation and exercise. In line with the statement, a study by Kodariyati \& Astuti (2016, pp.93-106) has found that the problem-based learning (PBL) that always initiates the mathematical learning process by assigning the mathematical problems has positive and significant influence on the students' mathematical problemsolving skills.

According to Souviney (1994, p.16), the indicators for assessing the mathematical problem-solving skills of Grade IV students are as follows: (1) the students are able to formulate the problems; (2) the students are able to implement numerous strategies for solving the problems; (3) the students are able to solve the mathematical problems or find the mathematical solutions; and (4) the students are able to verify or check and interpret the results in accordance to the preliminary problems. Then, in addition to improving the students' mathematical problem-solving skills the students' character of self-confidence should be developed because this character might support the students' learning achievement in the school. The results of a study show that selfconfidence in Mathematics has a significant role in the success of learning Mathematics (Schoenfeld in Hannula, Maijala \& Pekkonen, 2004, p.17). Then, Parsons, Croft \& Horrison (2011, p.53) state that self-confidence is a belief. The statement two implications. The first implication is that self-confidence and belief are two synonymous terms while the second implication is that self-confidence itself is a belief.

Similarly, Preston (2007, p.18) states that self-confidence is a perception about an individual's own personality with regards to both achievement and problem-solving skills. Therefore, self-confidence an important aspect that should be developed since the childhood. According to Preston (2007, p.15), confidence (or lack of it) is learned mostly in the first few years of childhood. Most of the sense of selfconfidence instead is learned during the childhood. As a result, there should be reinforcement from both the parents and the teachers to the children in order that the children's selfconfidence might be well-developed. Furthermore, Rokeach (1972, p.113) adds that the sense of self-confidence within an individual might be assessed from several conscious or unconscious statements that describe his or her self-perception. In line with the sense of self-confidence, a belief is any simple proposition, conscious or unconscious, inferred from what a person says or does, capable of being preceded by the phrase "I believe that ... "(Kislenko, Grevholm \& Lepik, 2005, pp.350-351). In other words, the phrase "I 
Jurnal Prima Edukasia, 7 (1), 2019 - 62

Suryatin Suryatin, Sugiman Sugiman

believe that ..." is commonly used for describing the sense of self-confidence that an individual has.

Departing from the above elaboration, it might be concluded that self-confidence in Mathematics for elementary school students refer to the self-skills for gaining learning achievements in Mathematics, for solving mathematical problems and for performing positive thinking skills in the learning process of Mathematics. In order to assess the students' sense of self-confidence, a questionnaire that contains the statement with the phrase "I believe that ..." will be developed. Then, the sense of self-confidence in Mathematics are assessed from four aspects. These aspects are confidence in Mathematics, confidence in own capability as student or user of Mathematics, confidence in the teaching process of Mathematics and confidence in the learning process of Mathematics (Hannula et.al, 2004, p.17). Furthermore, self-confidence might be defined gradually with two polarities namely weak confidence or strong confidence. In the same time, self-confidence might be categorized into two polarities such as certain or uncertain and significant or insignificant. According to Kislenko et al (2005, p.13), beliefs can be held weakly or strongly. The sense of self-confidence might be different from one individual to another. One may agree or disagree with the belief of another individual. As having been stated by Thompson, it is possible to believe something despite the awareness that the others do not agree with it and think about it differently (Breiteig, Grevholm \& Kislenko, 2005, p.131).

The character of self-confidence among the students is influenced by the intra-school and the extra-school factors. The intra-school factors that might be quite influential for the students within the Mathematics learning process are related to the Mathematics teachers in the form of the Mathematics teachers' curricular or learning decisions (Nurmi, Hannula, Maijala, \& Pehkonen, 2003, p.453). On the contrary, the extra-school factors are related to parents, relatives, peers and media (Nurmi et al., 2003, p.453). In addition, Elder (1995, p.62) states that the factors that influence self-confidence are peer acceptance and family. Similarly, gender might influence the students' self-confidence. The results from several studies show that the level of confidence among the male students is higher than that among the female students. Specifically, gender diffrences favouring males in confidence in Mathematics are well recorded (Hannula et al,
2004, p.18). Furthermore, Nunes, Bryant, Sylva, $\&$ Baros (2009, p.17) also propose several factors that might influence the different level of selfconfidence in relation to Mathematics. These factors include mathematical competencies, teacher perception and peer perception on the student's capacity, sex and verbal capacity.

Departing from the statements in the previous paragraph, it might be concluded that the students' character of mathematical selfconfidence might be influence by several matters. These factors are divided into two categories namely the intra-school factors and the extraschool factors. The intra-school factors are namely teachers' perception, classmates' perception, learning materials, competence under mastery and sex. On the contrary, the extraschool factors, that might be prominent, are related to acknowledgement and acceptance from the students' surrounding environment or, specifically, acknowledgement and acceptance by the parents in the students' family. Then, in relation to the mathematical self-confidence, a measurement is necessary to conduct in order to identify how far certain objectives have been meet. Similarly, Anderson (2000, p.7) states that assessments are usually made for some reason; that is, there is generally some purpose for which information is gathered. Therefore, in order to identify the improvement on the students' character of self-confidence a measurement should be conducted. Thus, the self-confidence, or specifically, the mathematical self-confidence might be measured through the instruments that have been designed based on the theories that have been reviewed. In specific, with regards to the measurement the questionnaire of selfconfidence within the study namely the aspects of mathematical confidence, the aspects of selfconfidence as a mathematical learner, the aspects of mathematical learning process-confidence and the aspects of mathematical teaching processconfidence.

Learning media as a medium for improving the learning quality might also serve as a medium for facilitating the students in training their problem-solving skills and in shaping their character of self-confidence. In relation to the statement, and based on the results of an interview with the classroom teachers of Grade IV Muhammadiyah Elementary School Condong Catur, it is found that the learning media in the school are still limited. Therefore, the development of learning media are highly necessary but unfortunately the teachers encounter obstacles 
Jurnal Prima Edukasia, 7 (1), 2019 - 63

Suryatin Suryatin, Sugiman Sugiman

from the aspect of time and the aspect of resources. Fortunately, comic as popular media with their characters might be adjusted to the desired learning objectives, such as shaping the character of self-confidence, in order to answer the problem of limited learning media. In addition, the examples of problem-solving activities might be modeled through the characters in the comic along with the provision of several examples. The possibility of using comic as learning media has been admitted by the teachers of Grade IV Muhammadiyah Elementary School Condongcatur since they admit that they the students prefer reading comics than subject textbooks. As a result, when these teachers are offered with the idea of using comic as part of the efforts in developing learning media they become very enthusiastic and they admit that using comic as learning media might be interesting. From the overall elaboration, the researcher might draw a conclusion that both the teachers and the students need comic-based learning media that might be used within the thematic-integrative learning process for improving the students' problemsolving skills and self-confidence character in the context of Grade IV Muhammadiyah Elementary School Condongcatur Yogyakarta.

\section{Method}

In conducting the study, the researcher referred to the research and development model by Gall, Gall, \& Borg (2007, p.775-776). The procedures in the model by Borg \& Gall consist of the following sequence: (1) research and information collecting; (2) planning; (3) preliminary form of product developing; (4) preliminary field testing; (5) main product revising; (6) main field testing; (7) operational product revising; (8) operational field testing; (9) final product revising; and (10) implementing. Then, the test toward the product that had been resulted from the study consisted of several stages namely: (1) product validation by material expert and media expert; (2) revision in accordance to the results of expert judgment; (3) preliminary field testing; (4) revision based on the results of preliminary field testing; (5) main field testing; (6) revision based on the results of main field testing; (7) operational field testing; and (8) revision based on the results of operational field testing.

The subjects that had been involved in the study were the students of Grade IV Muhammadiyah Elementary School Condongcatur Yogyakarta. The subjects in the preliminary field testing consisted of 6 respondents. Then, the subjects in the main field testing consisted of 30 studens who had not been involved in the preliminary field testing. Next, the subjects in the operational field testing consisted of 21 students who had not been involved in both the preliminary field testing and the main field testing. With regards to the subjects, the instruments within the study were divided into two categories namely the media validity instrument and the media effectiveness instrument. On the one hand, the media validity instrument consisted of the following parts: (1) material expert validation questionnaire; (2) media expert validation questionnaire; (3) teacher response toward comic questionnaire; and (4) student response toward comic questionnaire. On the other hand, the media effectiveness instrument consisted of: (1) test item on mathematical problem-solving skills capacity; and (2) students' self-confidence questionnaire.

The data in the study were the data from the material expert validation and the media expert validation with regards to the feasibility of the product that had been developed (comicbased learning media), the data from the questionnaire on both the teacher response on comic and the student response on comic, the data from the test on the problem-solving skills and the data from the questionnaire on the students' character of self-confidence. Within the study, the data were analyzed in order to identify the feasibility of the comic in supporting the learning process and the effectiveness of the comic-based learning media for improving the students' problem-solving skills and character of selfconfidence. In order to identify the quality of the comic-based learning media, the results of the development from the aspects of materials, the aspects of learning process and the aspects of layout, and also in order to identify the response of both the teachers and the students on the comic-based learning media, the data should be turned from numeric score into the qualitative data with five categories as the reference. According to Sukardjo (2006) the complete reference for the conversion of the numeric score into the qualitative data might be consulted in Table 1.

Then, the data from the results of problemsolving skills capacity test and the students' selfconfidence questionnaire were analyzed by means of paired t-test and independent t-test. Prior to performing the t-test, a prerequisite analysis test, which consisted of normality test and homogeneity test, should be performed. 
Jurnal Prima Edukasia, 7 (1), 2019 - 64

Suryatin Suryatin, Sugiman Sugiman

Tabel 1. Reference for Conversion into FiveScale Score

\begin{tabular}{ll}
\hline \multicolumn{1}{c}{ Score Internal } & \multicolumn{1}{c}{ Category } \\
\hline$X>\mathrm{M}_{\mathrm{i}}+1.8 \mathrm{Sbi}$ & Very Good \\
$\mathrm{M}_{\mathrm{i}}+0.6 \mathrm{Sbi}<X \leq \mathrm{M}_{\mathrm{i}}+1.8 \mathrm{Sbi}$ & Good \\
$\mathrm{M}_{\mathrm{i}}-0.6 \mathrm{Sbi}<X \leq \mathrm{Mi}+0.6 \mathrm{Sbi}$ & Moderately Good \\
$\mathrm{M}_{\mathrm{i}}-1.8 \mathrm{Sbi}<X \leq \mathrm{M}_{\mathrm{i}}-0.6 \mathrm{Sbi}$ & Quite Poor \\
$X \leq \mathrm{M}_{\mathrm{i}}-1.8 \mathrm{Sbi}$ & Poor \\
\hline Note: & \\
$\mathrm{Mi}=$ ideal mean score & \\
$=1 / 2$ (ideal maximum score + ideal minimum score $)$ \\
$\mathrm{X}=$ actual (empirical) score \\
$\mathrm{SBi}=$ ideal standard deviation \\
$=1 / 6$ (ideal maximum score - ideal minimum score $)$ \\
Ideal maximum score $=$ number of criteria items $\mathrm{x}$ \\
highest score \\
Ideal minimum score $=$ number of criteria items $\mathrm{x}$ \\
lowest score
\end{tabular}

\section{Results and Discussions}

Description of Product Development

At the beginning of the product development, the researcher gathered information through interview and literature review. After the researcher completed the information-gathering activities, the researcher proceeded to the development stages that consisted of comic draft design, material collection for the content of the comic, comic drawing activities, product validation by material expert and media expert, product analysis and product revision based on the suggestions provided by the material expert and the media expert. Then, the preliminary product that had been revised was sent to the preliminary field test. The preliminary field test was performed through the following procedures: (1) the researcher explained the product to the test subjects; (2) the test subjects studied the product that had been developed; and (3) the test subjects completed the response questionnaire. The number of test subjects (respondents) in the preliminary field test was 6 students and 1 teacher. The suggestions from the results of both the teacher response questionnaire and the student response questionnaire were analysed and later served as a matter of consideration for revision after the preliminary field test had been conducted.

After the revisions based on the results of the preliminary field test had been completed, the product was sent into another test namely the main field test. The main field test was performed under the following procedures: (1) the researcher explained the product to the test subjects; (2) the test subjects studied the product that had been developed; and (3) the test subjects completed the response questionnaire. The number of test subjects (respondents) in the main field test was 30 students and 1 teacher. The suggestions form the results of both the teacher response questionnaire and the student response questionnaire were analysed and later served as a matter of consideration for revision after the main field test had been conducted. When the revisions based on the results of the main field test had been completed, the product was sent to another test namely the operational field test. The operational field test was performed under the following procedures: (1) the researcher distributed the problem-solving capacity pre-test items and the self-confidence questionnaire; (2) the students completed the pretest items and the self-confidence questionnaire; (3) the students used the comic-based learning media within the learning process; (4) the students completed the problem-solving capacity post-test items and the self-confidence questionnaire while they were completing the response questionnaire for the comic-based learning media; and (5) the teacher completed the response questionnaire for the comic-based learning media. The number of test subjects (respondents) in the operational field testing was 21 students and 1 teacher. The suggestions from the both the teacher response questionnaire and the student response questionnaire in the operational field testing altogether with the findings within the operational field testing were analysed and served as a matter of consideration for performing the final product revision. On the other hand, the data on the students' problem-solving capacity and self-confidence were analysed in order to identify the effectiveness of the comic-based learning media.

\section{Description of Product Test}

Prior to performing the product test, the product should be validated first by the experts. The product validation by the material expert and the media expert was performed in order to attain the data on the media feasibility from the aspects of materials, learning process and layout. The minimum requirement of feasibility was that the general score from the overall aspects should be fallen into the "Good" category. If the requirement had been met then the media would have been considered feasible. Then, the conversion results of the validation score by the material expert and the media expert showed that the comic-based learning media that had been developed in general belong to the "Very Good" 
Jurnal Prima Edukasia, 7 (1), 2019 - 65

Suryatin Suryatin, Sugiman Sugiman

category. Thereby, the comic-based learning media that had been developed was considered valid and feasible for implementation in the subsequent process. With regards to the implementation, the suggestions that had been provided were related to pronunciation and term replacement (from "we" to "you"). On the contrary, the suggestions provided by the media experts were as follows: (a) the researcher should select softer colour; (b) the pictures should not hinder the writings; and (3) several pictures should be enlarged.

The revisions on the comic-based learning media were performed in accordance to the suggestions by the media expert. The data on the results of the product validation by the material expert were presented in Table 2. Then, the data on the results of the product validation by the media expert were presented in Table 3.

Table 2. Data on the Results of Validation by the Material Expert

\begin{tabular}{|c|c|c|c|c|}
\hline No. & $\begin{array}{c}\text { Assessment } \\
\text { Aspects }\end{array}$ & $\begin{array}{l}\text { Total } \\
\text { Score }\end{array}$ & $\begin{array}{l}\text { Maximum } \\
\text { Score }\end{array}$ & Category \\
\hline 1. & Materials & 42 & 50 & Good \\
\hline 2. & $\begin{array}{l}\text { Learning } \\
\text { Process }\end{array}$ & 39 & 45 & Very Good \\
\hline 3. & Layout & 30 & 35 & Very Good \\
\hline 4. & Total & 111 & 130 & Very Good \\
\hline
\end{tabular}

Table 3. Data on the Results of Validation by the Media Expert

\begin{tabular}{cccc}
\hline $\begin{array}{c}\text { Assessment } \\
\text { Aspect }\end{array}$ & $\begin{array}{c}\text { Total } \\
\text { Score }\end{array}$ & $\begin{array}{c}\text { Maximum } \\
\text { Score }\end{array}$ & Category \\
\hline Layout & 111 & 120 & Very Good \\
\hline
\end{tabular}

From the conduct of the preliminary field testing, the researcher found the data in the form of teacher response and student response toward the comic-based learning media. The conversion results of the score from the teacher response questionnaire showed that the comic-based learning media had belonged to the "Good" category with the score 109. On the other hand, the conversion results of the score from the student response questionnaire show that the comicbased learning media had belonged to the "Good" category with the score 82 . In this stage, the suggestion that had been provided by the teacher was tat the competencies from multiple subjects should be added and the researcher should pursue in-depth understanding on the discussions of the mathematical content. Within the test, the number of respondents was 1 teacher and six students. The data from the results of teacher response questionnaire were presented in Table 4 while the data from the results of student response questionnaire were presented in Table 5.

Table 4. Data from the Teacher Response on the Preliminary Field Test

\begin{tabular}{|c|c|c|c|c|}
\hline No. & $\begin{array}{l}\text { Assessment } \\
\text { Aspects }\end{array}$ & $\begin{array}{l}\text { Total } \\
\text { Score }\end{array}$ & $\begin{array}{l}\text { Maximum } \\
\text { Score }\end{array}$ & Category \\
\hline 1. & Materials & 42 & 50 & Good \\
\hline 2. & $\begin{array}{l}\text { Learning } \\
\text { Process }\end{array}$ & 37 & 45 & Good \\
\hline 3. & Layout & 30 & 35 & Very Good \\
\hline 4. & Total & 109 & 130 & Good \\
\hline
\end{tabular}

Table 5. Data from the Teacher Response on the Preliminary Field Test

\begin{tabular}{clccl}
\hline No. & $\begin{array}{c}\text { Assessment } \\
\text { Aspect }\end{array}$ & $\begin{array}{c}\text { Mean } \\
\text { Score Per } \\
\text { Student }\end{array}$ & $\begin{array}{c}\text { Maximum } \\
\text { Score }\end{array}$ & Category \\
\hline 1. & Materials & 28.8 & 35 & Baik \\
2. & Learning & 12.7 & 15 & Sangat \\
& Process & & & Baik \\
3. & Layout & 40.5 & 50 & Baik \\
4. & Total & 82.0 & 100 & Baik \\
\hline
\end{tabular}

After the product had been revised based on the suggestions that have been gathered from the preliminary field test, the comic-based learning media then were sent into the main field testing. The main field testing was performed by 1 teacher and 30 students who had not been involved in the preliminary field test. The data that had been attained were in the form of both the teacher response and the student response on the comic-based learning media. The conversion results of the score from the teacher response questionnaire showed that the comic-based learning media had belonged to the "Very Good" category with the score 112 . On the contrary, the conversion results of the score from the student response questionnaire showed that the comicbased learning media had belonged to the "Good" category with the score 73.5. The suggestions that had been provided by the teacher from the conduct of the main field test was that the researcher should insert several types of jokes in order that the comic-based learning media would be more interesting. The data on the teacher response toward the comic-based learning media might be consulted in Table 6 while the data on the teacher response toward the comic-based learning media might be consulted in Table 7 .

After the comic-based learning media had been revised based on the suggestions from the main field test, the comic-based learning media was sent to the operational field test. The operational field test involved 21 students of Grade IV Muhammadiyah Elementary School 
Jurnal Prima Edukasia, 7 (1), 2019 - 66

Suryatin Suryatin, Sugiman Sugiman

Condongcatur Yogyakarta. Within the conduct of the operational field test, the comic-based learning media was implemented into the learning process. The operational field test was performed in order to identify the feasibility of the comicbased learning media that had been tested previously. In addition, the operational field test was conducted in order to identify the effectiveness on the use of the comic-based learning media for improving the students' problem-solving skills and self-confidence. Then, the data that had been gathered from the operational field test were the data on the student response toward the comicbased learning media, the data on the test score of the students' problem-solving capacity before and after the learning process by means of comicbased learning media (pre-test and post-test) and the data on the students' self-confidence before and after the conduct of the learning process by means of comic-based learning media.

Table 6. Data from the Teacher Response within the Main Field Test

\begin{tabular}{|c|c|c|c|c|}
\hline No. & $\begin{array}{l}\text { Assessment } \\
\text { Aspects }\end{array}$ & $\begin{array}{l}\text { Total } \\
\text { Score }\end{array}$ & $\begin{array}{l}\text { Maximum } \\
\text { Score }\end{array}$ & Category \\
\hline 1. & Materials & 43 & 50 & Very Good \\
\hline 2. & $\begin{array}{l}\text { Learning } \\
\text { Process }\end{array}$ & 38 & 45 & Very Good \\
\hline 3. & Layout & 31 & 35 & Very Good \\
\hline 4. & Total & 112 & 130 & Very Good \\
\hline
\end{tabular}

Table 7. Data from the Student Response within the Main Field Test

\begin{tabular}{ccccl}
\hline \multirow{2}{*}{ No. } & $\begin{array}{c}\text { Assessment } \\
\text { Aspects }\end{array}$ & $\begin{array}{c}\text { Total } \\
\text { Score }\end{array}$ & $\begin{array}{c}\text { Maximum } \\
\text { Score }\end{array}$ & Category \\
\hline 1. & Materials & 26.1 & 35 & Good \\
2. & Learning & 11.4 & 15 & Good \\
& Process & & & \\
3. & Layout & 36.0 & 50 & Good \\
4. & Total & 73.5 & 100 & Good \\
\hline
\end{tabular}

The conversion results of the score from the teacher questionnaire in overall aspects show that the model had belonged to the "Very Good" category. On the other hand, the conversion results of the score from the student questionnaire in overall aspects show that the model had belonged to the "Good" category. Thereby, it might be concluded that the comic-based learning media that had been developed was feasible for implementation in the classroom learning process. The data from the results of the teacher questionnaire within the conduct of the operational field test might be consulted in Table 8 while the data from the results of the student questionnaire within the conduct of the operational field test might be consulted in Table 9 .
Table 8. Data from the Teacher Response within the Conduct of Operational Field Test

\begin{tabular}{|c|c|c|c|c|}
\hline No. & $\begin{array}{c}\text { Assessment } \\
\text { Aspects }\end{array}$ & $\begin{array}{l}\text { Total } \\
\text { Score }\end{array}$ & $\begin{array}{c}\text { Maximum } \\
\text { Score }\end{array}$ & Category \\
\hline 1. & Materials & 44 & 50 & Very Good \\
\hline 2. & $\begin{array}{l}\text { Learning } \\
\text { Process }\end{array}$ & 39 & 45 & Very Good \\
\hline 3. & Layout & 31 & 35 & Very Good \\
\hline 4. & Total & 114 & 130 & Very Good \\
\hline
\end{tabular}

Table 9. Data from the Teacher Response within the Conduct of Operational Field Test

\begin{tabular}{clccl}
\hline No. & $\begin{array}{c}\text { Assessment } \\
\text { Aspects }\end{array}$ & $\begin{array}{c}\text { Total } \\
\text { Score }\end{array}$ & $\begin{array}{c}\text { Maximum } \\
\text { Score }\end{array}$ & Category \\
\hline 1. & Materials & 27.7 & 35 & Good \\
2. & Learning & 13.4 & 15 & Very Good \\
& Process & & & \\
3. & Layout & 41.9 & 50 & Good \\
4. & Total & 82.9 & 10 & Good \\
\hline
\end{tabular}

After the operational field test had been completed, the researcher analysed the effectiveness of the comic-based learning media for improving the problem-solving skills. The data that the researcher analysed were the data that had been gathered from the pre-test results and the post-test results. The pre-test results referred to the problem-solving skills test that had been administered prior to the conduct of the learning process that involved the use of the comic-based learning media. On the other hand, the post-test results referred to the problem-solving skills test that had been administered after the conduct of the learning process that involved the use of the comic-based learning media. Consequently, the pre-test data described the preliminary level of the students' problem-solving skills while the post-test results described the level of the students' problem-solving skills after having been exposed to the comic-based learning media in the learning process. The differences between the pre-test results and the post-test results were analysed using the paired sample t-test in order to identify whether there had been significant improvement on the students' problem-solving skills or not after they had used the comic-based learning media in the learning process. H0 would be denied if sig. (1-tailed) value were lower than 0.05 (sig. (1-tailed) < 0.05). The data from the pre-test and the post-test results of the students' problem-solving skills might be consulted in Table 10.

Then, the researcher performed the t-test with $\mathrm{H}_{0}$ that postulated, "The post-test score of the students' problem-solving skills is lower than or equal to the pre-test score of the students' 
Jurnal Prima Edukasia, 7 (1), 2019 - 67

Suryatin Suryatin, Sugiman Sugiman

problem-solving skills" and the $\mathrm{H}_{1}$ that postulated, "The post-test score of the students' problemsolving skills is higher than or equal to the pretest score of the students' problem-solving skills." The results of the t-test toward the pre-test and the post-test score of the students' problemsolving skills might be consulted in Table 11.

Table 10. The Data from the Pre-Test Results and the Post-Test Results

\begin{tabular}{lrr}
\hline & $\begin{array}{c}\text { Pre-Test } \\
\text { Score }\end{array}$ & $\begin{array}{c}\text { Post-Test } \\
\text { Score }\end{array}$ \\
\hline Mean & 26.95 & 66.14 \\
Standard Deviation & 18.23 & 14.44 \\
Highest Score & 66 & 89 \\
Lowest Score & 5 & 45 \\
\hline
\end{tabular}

Table 11. The Results of the t-test for the Pre-

Test Score and the Post-Test Score of the

Students' Problem-Solving Skills

\begin{tabular}{cccc}
\hline $\begin{array}{c}\text { Type of } \\
\text { Test }\end{array}$ & $\begin{array}{c}\text { Sig. (1 } \\
\text { tailed })\end{array}$ & Note & Decision \\
\hline t-test & 0.00 & $<0.05$ & $\begin{array}{c}\mathrm{H}_{0} \text { should be } \\
\text { rejected }\end{array}$ \\
\hline
\end{tabular}

From the t-test results, it was apparent that one party of the paired-sample t-test had denied the $\mathrm{H}_{0}$. Therefore, it might be inferred that there had been significant improvement on the students' problem-solving skills after the comicbased learning media had been implemented in the learning process. In other words, the comicbased learning media that had been developed had been effectives in improving the students' problem-solving skills.

After the paired-sample t-test had been completed, the researcher proceeded to the analysis of the students' self-confidence questionnaire results. The data that had been analysed were the data from the students' self-confidence questionnaire prior to and after the implementation of the comic-based learning media in the learning process. The data from the students' self-confidence questionnaire prior to the implementation of the comic-based learning media in the learning process displayed the students' preliminary level of self-confidence. On the contrary, the data from the students' self-confidence questionnaire after the implementation of the comic-based learning media in the learning process displayed the students' final level of self-confidence. The different scores between the two students' selfconfidence questionnaires (before and after the implementation of the comic-based learning media in the learning process) were analysed by means of paired-sample t-test in order to identify whether there had been significant improvement on the students' self-confidence or not after the students had used the comic-based learning media in the learning process. The data from the students' self-confidence questionnaire results before and after the implementation of the comicbased learning media in the learning process might be consulted in Table 12 .

Table 12. The Data from the Students' SelfConfidence Questionnaire Results

\begin{tabular}{|c|c|c|}
\hline & \multicolumn{2}{|c|}{$\begin{array}{c}\text { Score of Self-Confidence } \\
\text { Questionnaire }\end{array}$} \\
\hline & Preliminary & Final \\
\hline Mean Score & 85.81 & 95.52 \\
\hline Deviation Standard & 19.04 & 9.61 \\
\hline Lowest Score & 103 & 110 \\
\hline Highest Score & 11 & 79 \\
\hline
\end{tabular}

Then, the researcher performed the t-test analysis with the $\mathrm{H}_{0}$ that postulated, "The final score of the students' self-confidence questionnaire is lower than or equal to the preliminary score of the students' self-confidence questionnaire" and the $\mathrm{H}_{1}$ that postulated, "The final score of the students' self-confidence questionnaire is higher than or equal to the preliminary score of the students' self-confidence questionnaire." $\mathrm{H}_{0}$ would be denied if sig. (1-tailed) value were lower than 0.05 (sig. (1-tailed) value < 0.05). The results of the t-test toward the students' preliminary self-confidence results and the students' final self-confidence results might be consulted in Table 13.

Table 13. The Results of the t-test toward the Students' Preliminary and Final Self-Confidence Results

\begin{tabular}{cccc}
\hline $\begin{array}{c}\text { Type of } \\
\text { Test }\end{array}$ & $\begin{array}{c}\text { Sig. } \\
(1 \text { tailed })\end{array}$ & Note & Decision \\
\hline t-test & 0.0075 & $<0.05$ & $\begin{array}{c}\mathrm{H}_{0} \text { should be } \\
\text { rejected }\end{array}$ \\
\hline
\end{tabular}

From the results of the t-test (Tabel 13), it was apparent that one party within the pairedsample t-test denied the $\mathrm{H}_{0}$. Therefore, it might be concluded that there had been significant improvement on the students' self-confidence after the implementation of the comic-based learning media in the learning process. In other words, the comic-based learning media that had been developed had been effective in improving the students' character of self-confidence.

Discussions

The use of the comic-based learning media in the thematic-integrative learning process has 
Jurnal Prima Edukasia, 7 (1), 2019 - 68

Suryatin Suryatin, Sugiman Sugiman

been effective in improving the students' problem-solving skills and self-confidence character. The use of the comic-based learning media in the teaching-learning activities has caused the learning situations to be more enjoyable and the students to be more actively involved in the teaching-learning activities, the knowledgebuilding activities and the self-characters. Based on the results of the validation by the material expert and the media expert, the comic-based learning media that have been developed belong to the "Very Good" category from the overall aspects of general assessment. Thereby, the comic-based learning media if feasible and ready for further field test.

Then, based on the teacher-response questionnaire, the comic-based learning media that have been developed belong to the "Good" category in the preliminary field test and the "Very Good" category from the overall aspects of general assessment. On the other hand, based on the student-response questionnaire, the comicbased learning media that have been developed belong to the "Good" category in the preliminary field test and the "Very Good" category from the overall aspects of general assessment. Therefore, it might be concluded that the comic-based learning media have been feasible for implementation based on the results of both the teacher-response questionnaire and the student-response questionnaire.

The objective of developing the comicbased learning media is to encounter the following problems: (a) the limited learning media available in the elementary school; (b) the low learning interest of the students; and (c) the low problem-solving skills and self-confidence among the students. Departing from the results of the field operational test, it is found that the use of the comic-based learning media in the learning process has been able to improve the problemsolving skills of the Grade IV students in the Muhammadiyah Elementary School Condongcatur Yogyakarta.

During the preliminary field test, approximately 6 students from Grade IV of Muhammadiyah Elementary School Condongcatur Yogyakarta performed the learning process by means of the comic-based learning media that had been developed and responded to the comic. When the students read the comic, the researcher observed and took notes on the students' activities. During these moments, the researcher found that the students had enthusiastically read the comic. The students read seriously read the comic one page after another and it seemed that they had been interested in the comic, that had been full of pictures with bright colours. In addition, they seemed to enjoy the learning process by reading the comic. The comic was intentionally designed with bright pictures and colours in order to draw the students' interest to learn by still paying attention to the content of the learning process that the students should lead. Then, in the preliminary field test it was confirmed that the layout of the pictures and the colours had been able to draw the students' interest. This finding is in accordance to the theory by Tabrani (2014, p.20) who postulates that children are easier to communicate by means of pictorial language because they have already been familiar to the picture than the writing.

The results of the students' response show that all students have been interested in the comic-based learning media that have been developed and the students state that learning by means of the comic is totally enjoyable. The students' interest to read the comic is in accordance to the theory by Sudjana \& Rivai (2013, p.68) who have postulated that one of functions that the comic has is to increase the students' interest. In addition, Tatalovic (2009, p.1) state that comic is one of the popular media among the children. By using the comic, the teacher is able to increase the students' reading interest and to facilitate the students to actively and enthusiastically attend the teaching-learning process. Within the results of the student-response questionnaire, the students also state that the learning process by means of the comic has made them to enthusiastically attend the learning process. This statement is in accordance to the statement by Sadiman, et.al. (2012, pp.17-18) who state that media are able to encounter the students' passive character by arounding their learning enthusiasm.

Then, the results of the preliminary field test for the comic-based learning media are also in accordance to the results of the study by Cheesman (2006, pp.48-51), which show that most of the students are happy when they are learning by means of comic-based learning media although not all students display positive response toward the use of the comic in the learning process. However, in the context of the study within the preliminary field test the students display positive response toward the use of the comic-based learning media within the learning process.

In the main field test, the comic-based learning media was tested to the Grade IV 
Jurnal Prima Edukasia, 7 (1), 2019 - 69

Suryatin Suryatin, Sugiman Sugiman

students of Muhammadiyah Elementary School Condongcatur Yogyakarta with more test subjects namely 31 people. When the students read the comic, the researcher observed and took notes on the students' activities. It seemed that the students had been enthusiastically reading the comic. The students read one page after another carefully as having been similar to the preliminary field test. The students' interest is one of the objectives that the researcher would like to achieve within the learning media development. This interest then encourages the students to read and by means of reading activity the students will be able to look for information that support the reading materials in the comic. During the main field test, the students also took time to discuss the lessons that they found in the comic.

The establishment of this discussion process is in accordance to the theoretical review by Sadiman, et. al. (2012, p.7), which has found that learning media might stimulate the students' cognition, sense, attention and interest in such a way that the learning process takes place. In addition, learning media also enables the students to learn independently in accordance to their capacity and interest and in the same time encourages the students to learn actively. In other words, through reading comic and holding discussions the students will be able to look for and construct knowledge.

The students are interested in the comicbased learning media because basically comic is a light reading material that has been able to draw the reading interest of the children. In addition, comic is able to help the students in understanding the learning materials through the active learning process. With regards to the statement, the results of previous studies have found the relationship between the comic-based learning media and the learning achievement (for instance: Indaryati \& Jailani, 2015, pp.84-96). Their study deals with the development of the comic for the mathematical learning process for improving the motivation and the learning achievement of the elementary students within the narrative test items under the following materials: distance, time and speed. The results of their study show that the learning process by means of the comic that has been developed is able to improve the students' motivation and learning achievement.

The comic-based learning media that has been developed is also able to facilitate the students in exploring their problem-solving skills through the worksheet and the exercise items on the core part of the comic. Actually, the worksheet and the exercise items on the core part of the comic serve as the room for the students' exploration in performing the stages of problemsolving skills. The exercise items in the core part of the comic begins with an example by the characters in the comic and then the students should complete the missing parts within the conversation column and these missing parts serve as the place for performing the stages in the mathematical problem-solving skills as follows: (a) problem formulation; (b) strategy plan; (c) problem-solving; and (d) re-check. In addition, the comic is also equipped by the exercise items of the problem-solving skills. These skills are exercised after the students understand and perform the stages of problem-solving skills in the core part of the comic. In line with the statement, the worksheet for exploring the students' capacity in solving the problems of data presentation by means of column chart can be found in the core part of the comic. As a result, the students might use the comic as their learning media and their worksheet.

As having been stated by Poyla (1973, p.5), problem-solving skills refer to the practical skills that might be attained by means of imitation and trial. Consequently, the frequency of the students in performing exercises will influence the level of the problem-solving skills. This statement is supported by the statement from Musser et. al (2011, p.4), which defines that performing exercises will be very useful in increasing the students' problem-solving skills because through the exercise the stusents will be able to understand the concepts, the characteristics and the procedures that later will be implemented in solving the mathematical problems. Similarly, the results of a study by Kodariyati \& Astuti (2016, pp.93-106) show that problem-based learning model (PBL) that always leads the conduct of the mathematical learning process has positive and significant influence on the mathematical problem-solving skills.

The use of comic in the learning process also facilitates the small discussions between the students as having been found in the four operational field tests. In one of the operational field tests, the students performed the role-play game. In this role-play game, one student became the teacher while the other one became the student. The student who became the student in the comic played guessing games by imitating directly the actions in the comic. Within the 
Jurnal Prima Edukasia, 7 (1), 2019 - 70

Suryatin Suryatin, Sugiman Sugiman

process, the student who became the teacher in the comic automatically should have more insight than his peers. Consequently, this student gained his courage to give questions to his peers so that the game might proceed well.

When the student who became the teacher in the comic had difficulties, he raised his question to the classroom teacher because he realized that he should have more insights than his peers. On the other hand, the students who became the student in the comic should actively look for the answer from his teacher because he did not want to lose from his pair in the role-play. This kind of learning situation displays the situation of active learning process in which each student strives forward to build their knowledge and hone their skills. The materials that they studied during the role-play was the data presentation by means of line chart. The thing that the students mostly asked was the way to read the data from the line chart which value had been located in the two-digit intervals.

At the beginning, the students were still confused in defining the value that the line chart had pointed to within the two-digit intervals. This confusion then became the starting point for the students to solve their problems by means of guess and check-method, which has been one of the tricks in solving the problems. In order to ensure that the guess of the students had been correct, the students should ask the teacher. The question itself appeared due to the students' own awareness in order to clarify (check) the truth of the answer. Thereby, it might be concluded that the comic-based learning media that has been developed has concrete influence on facilitating the students to actively build their knowledge and problem-solving skills. After the results of the study have been analysed, it is confirmed that the learning process for the problem-solving skills by means of the comic-based learning media that has been developed has been effective in improving the students' problem-solving skills.

The results of the paired-sample t-test on the pre-test score and the post-test score of the problem-solving skills with the rate of significance 0.05 show that sig. (1-tailed) $=0.00$ $<0.05$. Based on the results, the null hypothesis should be rejected and thus the conclusion is that the post-test score of the problem-solving skills is higher than the pre-test score of the problemsolving skills. In other words, there has been improvement on the students' problem-solving skills after they have implemented the comicbased learning media into the learning process.
Then, in addition to improving the students' problem-solving skills, the learning process by means of the comic-based learning media with the role-play game variation is able to improve the students' self-confidence. One of the evidences for the improvement on the students' self-confidence is that the students are encouraged to play the role as a teacher in order to raise questions and evaluate the answers of their peers. In the same time, the students are encouraged to raise questions to the teachers under their own awareness, the students are still enthusiastic in answering the questions from their peers and the students tend to display higher sense of curiosity (shown by their encouragement to ask to the peers and to the teachers and also to find information from multiple learning sources).

Furthermore, the students display their self-confidence in completing the exercise items after they have been actively involved in the learning process. The students are not lazy anymore in exercising themselves because they have already been equipped to complete the exercise items from the learning process that has been performed. Then, during the completion of the exercise items, the students have encouragement to ask the things that they do not understand and they do not leave the classroom with lack of knowledge and self-confidence anymore. Based on these conditions, there is an indication that the students' self-confidence has improved.

Based on the results of the data analysis for the self-confidence questionnaire, it is confirmed that the learning process by means of the comicbased learning media has been able to improve the students' self-confidence. The results of paired-sample t-test toward the preliminary and the final results of the self-confidence questionnaire with the rate of significance 0.05 show that sig. $(1$-tailed $)=0.075$ or lower than 0.05 . Based on the results of the t-test, the null hypothesis should be rejected. Thus, it might be concluded that the final score of the students' self-confidence questionnaire is higher than the final score of the preliminary score of the students' self-confidence questionnaire. In other words, the students' self-confidence has improved after the implementation of the comicbased learning media into the learning process. Then, the empirical findings from the field that comic has been able to make the students more self-confident support the results of the study by Saputro \& Soeharto (2015, pp.61-72) about the development of a comic that might improve the 
Jurnal Prima Edukasia, 7 (1), 2019 - 71

Suryatin Suryatin, Sugiman Sugiman

students' character values. in the same time, the empirical findings are also in accordance to the theory which stipulates that comic has been able to ease the readers in identifying their selfcharacters as having found by Sudjana \& Rivai (2013, p.64).

Departing from the overall discussions, the final conclusion that might be drawn is that the comic-based learning media that has been developed has been feasible for implementation into the thematic-integrative learning process for the Grade IV students of Muhammadiyah Elementary School Condongcatur Yogyakarta. In addition, the other final conclusion that might be drawn is that the comic-based learning media that has been developed has been able to improve the students' problem-solving skills and selfconfidence. These conclusions are in line with the results of the study by Cheesman (2006, pp.4851) and also Indaryati \& Jailani (2015, pp.84-96), namely that the comic-based learning media is able to improve the students' cognitive capacity. Within the study by Cheesman, the comic-based learning media has been able to improve the students' critical thinking skills; on the other hand, within the study by Indaryati \& Jailani the comic-based learning media has able to improve the students' learning achievement on the narrative test items. Specific to the context of the study, the comic-based learning media has been able to improve the students' mathematical problem-solving skills.

Last but not the last, in terms of selfconfidence improvement the results of the study are in line with the results of the study by Saputro $\&$ Soeharto (2015, pp.61-72). In their study, the comic that has been developed has been effective to improve the students' character of discipline and responsibility. On the other hand, specific to the context of the study, the comic-based learning media has been able to improve the students' selfconfidence.

\section{Conclusions}

The results of the study show that the comic-based learning media that has been developed is feasible for implementation in the thematic-integrative learning process for the Grade IV students of Muhammadiyah Condongcatur Yogyakarta based on the validation by the material expert, the media expert, the teacher's response and the students' response. In addition, the comic-based learning media that has been developed has been feasible for improving the students' mathematical problem-solving skills and self-confidence character in the context of Grade IV of Muhammadiyah Elementary School Condongcatur Yogyakarta.

\section{References}

Anderson, L. W. (2000). Assesing affective characterstics in the schools $\left(2^{\text {nd }} e d\right)$. New Jersey: Lawrence Erlbaum Associates, Inc.

Breiteig, T., Grevholm, B., \& Kislenko, K. (2005). Beliefs and attitudes in mathematics teaching and learning. Nordisk Konferanse i Matematikkdidaktikk ved NTNU: 15/11/2004-16/11/2004, pp. 129-138. Department of Geography, Norwegian University of Science and Technology.

Cheesman, K. (2006). Using comics in the science classroom. Journal of College Science Teaching, 35, (4), 48-51.

Elder, G. H., Jr. (1995). Life trajectories in changing societies. In A. Bandura (Ed.), Self-efficacy in changing societies (pp. 4668). New York, NY: Cambridge University Press. doi:http://dx.doi.org/10.1017/CBO978051 1527692.004

Gall, M. D., Gall, J. P., \& Borg, W. R. (2007). Educational research: An introduction. Boston: Pearson/Allyn \& Bacon.

Gumelar, MS. (2011). Cara membuat komik. Jakarta: Indeks.

Hannula, M. S., Maijala, H., \& Pehkonen, E. (2004). Development of understanding and self-confidence in mathematics; grades 58. Proceedings of the 28th Conference of the International Group for the Psychology of Mathematics Education, 3, 17-24.

Haylock, D. (2007). Key concepts in teaching primary mathematics. London: Sage Publications.

Indaryati, I., \& Jailani, J. (2015). Pengembangan media komik pembelajaran matematika meningkatkan motivasi dan prestasi belajar siswa kelas V. Jurnal Prima Edukasia, 3(1), 84-96. doi:https://doi.org/10.21831/jpe.v3i1.4067

Kementerian Pendidikan dan Kebudayaan. (2014). Pahlawanku: Buku guru/kementerian pendidikan dan kebudayaan. Jakarta: Kementerian Pendidikan dan Kebudayaan. 
Jurnal Prima Edukasia, 7 (1), 2019 - 72

Suryatin Suryatin, Sugiman Sugiman

Kislenko, K., Grevholm, B., \& Lepik, M. (2007). Mathematics is important but boring: Students' beliefs and attitudes towards mathematics. Nordic Conference on Mathematics Education: 02/09/200506/09/2005 (pp. 349-360). Tapir Academic Press.

Kodariyati, L., \& Astuti, B. (2016). Pengaruh model PBL terhadap kemampuan komunikasi dan pemecahan masalah matematika siswa kelas V SD. Jurnal Prima Edukasia, 4(1), 93-106. doi:https://doi.org/10.21831/jpe.v4i1.7713

Musser, G. L., Peterson, B. E., \& Burger, W. F. (2013). Mathematics for elementary teachers, binder ready version: A contemporary approach. John Wiley \& Sons, Inc.

NCTM. (2000). Principles and standards for school mathematics. Reston, VA

Nunes, T., Bryant, P., Sylva, K., \& Barros, R. (2009). Development of maths capabilities and confidence in primary school (Research Report DCSF-RR118). London: Department for Children, Schools and Families (DCSF). Retrived from https://dera.ioe.ac.uk/11154/

Nurmi, A., Hannula, M., Maijala, H., \& Pehkonen, E. (2003). On pupils' selfconfidence in mathematics: Gender comparisons. International Group for the Psychology of Mathematics Education, 3, 453-460.

Parsons, S., Croft, T., \& Harrison, M. (2011). Engineering students' self-confidence in mathematics mapped onto Bandura's selfefficacy. Engineering Education, 6(1), 5261.doi:

https://doi.org/10.11120/ened.2011.06010 052

Pimta, S., Tayraukham, S., \& Nuangchalerm, P. (2009). Factors influencing mathematic problem-solving ability of sixth grade students. Journal of Social Sciences, 5(4), 381-385. doi:10.3844/jssp.2009.381.385

Polya, G. (1973). How to solve it: A new aspect of mathematical method. Princeton: Princeton University Press.
Posamentier, A. S., \& Krulik, S. (2009). Problem solving in mathematics, grades 3-6: Powerful strategies to deepen understanding. Corwin Press.

Preston, D. W (2007). 365 steps to self confidence, Oxford: British Library cataloguing.

Runtukahu, T., \& Kandou, S. (2014). Pembelajaran matematika dasar bagi anak berkesulitan belajar. Yogyakarta: Ar-Ruzz Media.

Russell, D. L., \& Schneiderheinze, A. (2005). Understanding innovation in education using activity theory. Journal of Educational Technology \& Society, 8(1), 38-53.

Sadiman, A., Rahardjo, R., Haryono, A., \& Rahardjito, R. (2012). Media pendidikan: Pengertian penelitian dan pemanfaatannya. Jakarta: PT Raja Grafindo Persada.

Saputro, H.B, \& Soeharto, S. (2015). Pengembangan media komik berbasis pendidikan karakter pada pembelajaran tematik-integratif kelas IV SD. Jurnal Prima Edukasia, 3(1), 61-72. doi:https://doi.org/10.21831/jpe.v3i1.4065

Sudjana, N. \& Rivai, A. (2013). Media pengajaran. Bandung: Sinar Baru Algesindo Offset.

Sukardjo, S. (2006). Kumpulan materi evaluasi pembelajaran. Yogyakarta: Universitas Negeri Yogyakarta

Tabrani, P. (2014). Proses kreasi gambar anak. Jakarta: Erlangga.

Tatalovic, M. (2009). Science comics as tools for science education and communication: a brief, exploratory study. Journal of Science Communication, 8(4), A02. doi:https://doi.org/10.22323/2.08040202

Tyagi, P. (2014). Teaching a course with active learning approaches and training other teachers about deep learning stretegies. International Journal of Innovation Education and Research, 2(12), 14-23. Retrieved from https://ijier.net/index.php/ijier/article/view $/ 281$ 